\title{
IMPACT OF SOME ALTERNATIVE FERTILIZERS SUCH AS ANHYDROUS AMMONIA, HUMIC ACID, ROCK PHOSPHATE AND FELDSPAR ON GROWTH, YIELD AND ITS COMPONENTS AND NUTRIENT UPTAKE OF WHEAT AS WELL AS NUTRIENT AVAILABILITY
}

Ismail, S.A., Abd El-Hafeez, A.M. and Galal,O.A. and Awadalla, H.A Soil, Water and Environment, Res. Inst., A.R.C.

\section{ABSTRACT:}

The effect of some alternative fertilizers, namely anhydrous ammonia in comparing with urea, humic acid, rock phosphate and feldspar on growth, yield and its components and nutrient uptake and its availability in soil after harvest for wheat plant (cv Beni Swif 1) were evaluated in a field experiment. The experiment was conducted at Sids Agricultural Research Station (ARC) Beni Swif Governorate 2010/2011 and 2011/2012 seasons in split plot design. Nitrogen sources, i.e. anhydrous ammonia or urea at rate of $75 \mathrm{~kg} \mathrm{~N} / \mathrm{fed}$ were located in the main plots. While, natural fertilizer treatments (without, humic acid, rock phosphate, and feldspar and their combinations at rates of 10,300 and $400 \mathrm{~kg} /$ fed respectively) were added in the sub plots.

The results show that anhydrous ammonia significantly produced tallest and heaviest plants, more numbers of both spikes $/ \mathrm{m}^{2}$ and grains/spike as well as higher 1000 grain weight and grain and straw yields when compared with urea. Also, plants incorporated with anhydrous ammonia absorbed more $\mathrm{N}, \mathrm{P}$ and $\mathrm{K}$ than that with urea. Injected the soil with anhydrous ammonia significantly improved soil available nitrogen after wheat harvest, while soil available $\mathrm{P}$ and $\mathrm{K}$ were not affected. The treatments effects of natural fertilizers comparing with, without natural fertilizers on growth parameters (plant height, dry weight/plant, number of spikes $/ \mathrm{m}^{2}$, number of grains/spike and grain and straw yields) could be arranged in the following descending order: humic acid > rock phosphate > feldspar. Combined humic acid with rock phosphate and /or feldspar were enhanced its effects than sole applications. Humic acid, rock phosphate or feldspar yielded highest N, P and K uptake by grain and straw, when compared with control. Combined natural fertilizers with each other produced more nutrient uptake than the single one. Humic acid application enhanced soil available $\mathrm{N}, \mathrm{P}$ and $\mathrm{K}$, however rock phosphate and feldspar significantly improved soil available $\mathrm{P}$ and $\mathrm{K}$, respectively than untreated control.

Key words : Anhydrous ammonia, urea, rock phosphate, feldspar, wheat, growth parameters, wheat yield, nutrient uptake and its availability.

Fayoum J. Agric. Res. \& Dev., Vol. 28, No.1, January, 2014 
INTRODUCTION:

Agricultural production in Egypt mainly depends on chemical fertilizers and the rates of their consumption, per unit area are more than the averages of the whole world. However, because of shortages in some fertilizers supplies, and currents costs of energy used in their production, the cost of fertilizers has risen tremendously and will continue rise. In view of the economical and environmental problems of using chemical fertilizers, utilization of ammonia gas and natural fertilizers, e.g. rock phosphate, feldspar and humic acid would not only resulted in increasing soil fertility and crop production through its additional nutrients supply, but would also help in solving sanitary and environmental problems, as well as would save foreign currency for Egypt.

Humic acids mainly produced from nitrogenous compounds containing decomposed amino acids and aromatic complexes (Andriesse, 1988). Those organic complexes affect soil properties and physiological properties of plants due to carboxyl $\left(\mathrm{COOH}^{-}\right)$and phenolic $\left(\mathrm{OH}^{-}\right)$groups (Schnitzer, 1992). It enhances plant growth by chelating unavailable nutrients and buffering $\mathrm{pH}$ (Tahir et al, 2011). However, their effects on soil have not yet been clearly elucidated. In many studies, humic acids were reported to increase the uptake of mineral elements (Khaled and Fawzy, 2011), to promote root length (Canellas et al, 2002), to increase the fresh and dry weights of crop plants (Chen et al, 2004 and Akinci et al, 2009). Ulukan (2008) reported that humic acid had positive effect on wheat growth and yield and its components. Furthermore, Shahryari and Mollasedeghi (2011) found that humic acid decreased drought stress intensity and increased economic and biological yield of wheat.

In Egypt, many authors reported the superiority of using anhydrous ammonia than other nitrogen fertilizers such as Morsy (1994), Abd ElHamed et al, (1996), Ismail et al (1996), Abd El-Kader (2002), El-Masry et al (2006) and Siam et al (2008). There are several reasons why anhydrous ammonia is used so widely, first because anhydrous ammonia is the initial step in the manufacture of almost all commercial $\mathrm{N}$ and second it is the least costly source of fertilizers N. Also it contains the highest nutrient concentration $(82.5 \% \mathrm{~N})$.

On the other hand, Rajan et al (1996), Hellal et al (2009), Massoud et al, (2009) and El Sheref (2012) indicated that direct application of rock phosphate and feldspar materials may be ergonomically more useful and environmentally more feasible than soluble $\mathrm{P}$ and $\mathrm{K}$. Also, it improved growth, yield and chemical composition of plant as mineral fertilizers. They added that, the natural fertilizers reduce contamination which is caused by chemical fertilizers and produce healthy and safe plants, as well as the fact that natural fertilizers have less cost than chemical one.

The objective of the present investigation is to evaluate the effect of some natural fertilizers, i.e. rock phosphate, feldspar and humic acid under two nitrogen sources, namely urea and ammonia gas on wheat productivity and soil fertility.

Fayoum J. Agric. Res. \& Dev., Vol. 28, No.1, January, 2014 
IMPACT OF SOME ALTERNATIVE FERTILIZERS SUCH AS..........91 MATERIALS AND METHODS:

In order to study the effects of humic acid, rock phosphate and feldspar under two nitrogen sources on productivity of wheat (c.v. Beni Swif 1) as well as on soil fertility after harvest, two seasons field experiment was done on 2010/2011 and 2011/2012 seasons. The experimental design was factorial in split plot with four replicates. The first factor was two nitrogen sources (ammonia gas and urea) and the second factor was natural fertilizers and their combination (without, humic acid at rate of $10 \mathrm{~kg} / \mathrm{fed}$, rock phosphate at rate of $300 \mathrm{~kg} / \mathrm{fed}$, feldspar at rate of $400 \mathrm{~kg} / \mathrm{fed}$, humic acid + rock phosphate, humic acid + feldspar, rock phosphate + feldspar and humic acid + rock phosphate + feldspar).

\section{Experiment location:}

The experiment was done at the Farm of Sids Agricultural Research Station, ARC, Beni Swif Governorate, Egypt. A representative surface soil sample was collected from the experimental site at the depth of $0.0-30 \mathrm{~cm}$ before planting. Also, similar representative soil samples were collected after harvest from each plot in both seasons. Some chemical and physical soil properties for the sample before planting and soil available N, P and $\mathrm{K}$ in soil after harvest were determined according to Jackson (1973) and listed in Table (1). Table (1): Physical and chemical properties of the soil before planting under two different seasons.

\begin{tabular}{|l|c|c|}
\hline Soil properties & First season & Second season \\
\hline Particle size distribution & & \\
Sand \% & 16.03 & 17.28 \\
Silt \% & 29.72 & 30.11 \\
Clay \% & 54.25 & 52.61 \\
Texture grade & Clay & Clay \\
$\mathrm{pH}(1: 2.5$ soil-water suspension) & 8.17 & 8.05 \\
$\mathrm{EC}, \mathrm{dSm}^{-1}$ (soil paste ) & 0.35 & 0.38 \\
Organic matter $(\%)$ & 1.78 & 1.85 \\
$\mathrm{CaCO}_{3}(\%)$ & 2.15 & 2.71 \\
Available $\mathrm{N} \quad \mu \mathrm{g} \mathrm{g}^{-1}$ & 25.11 & 26.37 \\
Available P $\mathrm{\mu g} \mathrm{g}^{-1}$ & 10.15 & 12.35 \\
Available K $\mathrm{\mu g} \mathrm{g}^{-1}$ & 186.00 & 195.00 \\
\hline
\end{tabular}

Fertilizer treatments:

Nitrogen sources: two nitrogen fertilizer sources, i.e. anhydrous ammonia (ammonia gas, $82.5 \% \mathrm{~N}$ ) and urea $(46.5 \% \mathrm{~N})$ were applied at rate of $75 \mathrm{~kg} \mathrm{~N} / \mathrm{fed}$ in the main plots. Ammonia gas was injected directly into moderately moisture soil at $15 \mathrm{~cm}$ depth with $30 \mathrm{~cm}$ spacing between points of injection before sowing. Whereas, urea was added at two equal doses, before the first and the second irrigation.

Natural fertilizers, namely, humic acid, rock phosphate, feldspar were randomizely added before sowing at rates of 10, 300 and $400 \mathrm{~kg} / \mathrm{fed}$ in the sub plot, respectively. The treatments were (without, humic acid, rock phosphate, and feldspar and their combinations .

Fayoum J. Agric. Res. \& Dev., Vol. 28, No.1, January, 2014 


\section{Field experiment:}

Wheat grains, c.v. Beni Swef 1 were planted in plots (plot area was $13.5 \mathrm{~m}^{2}$ $=1 / 311 \mathrm{fed}$ ) in November $17^{\text {th }}$ and $21^{\text {th }}$ in the first and second seasons, respectively. At maturity, wheat plants were harvested in May and plant growth parameters (plant height $(\mathrm{cm})$, dry weight/plant $(\mathrm{g})$, number of spikes $/ \mathrm{m}^{2}$, number of grains/spike, 1000 grain weight $(\mathrm{g})$, grain yield (ardab/fed) and straw yield $(\mathrm{t} / \mathrm{fed})$ were recorded. Samples of grains and straw were taken and dried, then ground to powder for N, P and $\mathrm{K}$ analysis according to Chapman and Pratt (1961), and the total N,P and $\mathrm{K}$ uptake in grains plus straw were calculated. All other cultural practices for wheat production in the area were done. All collected data were statistically analyzed according to the procedure described by Snedecor and Cochran (1980).

\section{RESULTS:}

\section{1-Plant growth parameters:}

Nitrogen sources and natural fertilizers reveal a significant effect on plant height and dry weight of wheat at maturity in both seasons. Table (2) show that ammonia gas $\mathrm{N}$-dressing supported better plant growth compared with urea with relative increases in plant height and dry weight of 1.1 and $2.6 \%$ in the first season, respectively. The corresponding relative increases in the second seasons were 0.70 and $1.3 \%$.

Effect of natural fertilizers exceeded that without natural addition. It could arrange the effect of natural fertilizers on wheat growth in the descending order as follows: humic acid + rock $\mathrm{P}+$ feldspar $>$ humic acid + rock $\mathrm{P}>$ humic acid + feldspar $>$ rock $\mathrm{P}+$ feldspar $>$ humic acid $>$ rock $\mathrm{P}>$ feldspar $>$ without natural fertilization. Combined the three natural fertilizers resulted in 6.2 and $2.75 \%$ taller and heaviest wheat in the first season. The same trend, were obtained in the second season.

Among the natural fertilizes, humic acid was superior fertilizer in respect of growth enhancement, where resulted in $109.8(\mathrm{~cm})$ and $3.94(\mathrm{~g})$ of wheat plant height and dry weight/plant in the first season. This was followed by rock $\mathrm{P}(108.8, \mathrm{~cm}$ and $3.88, \mathrm{~g})$ and feldspar $(107.9$, $\mathrm{cm}$ and 3.78) in the abovementioned respect. The interaction between nitrogen sources and natural fertilizers was not significant, as the highest values of wheat growth was observed in mixed of the three natural fertilizers under ammonia gas addition. Under this treatment the values of plant height and dry weight/plant were $114.3(\mathrm{~cm})$ and $4.53(\mathrm{~g})$, respectively in the first season. The lowest plant height or dry weight under interaction treatments was observed when urea was used as nitrogen fertilizer without natural fertilizers application.

\section{2-Yield components}

Number of spikes $/ \mathrm{m}^{2}$, number of grains/spike and 1000-grains weight as affected by nitrogen sources and natural fertilizers are given Table (2). Statistical analysis show significant differences for yield component parameters between wheat plants due to nitrogen sources. Application of nitrogen as ammonia gas resulted in more number of spikes $/ \mathrm{m}^{2}$, more number of grains/ spike and heaviest grains compared with plants received nitrogen as urea in both seasons. The relative increases due to ammonia gas for these parameters were $3.5,3.2$ and $0.7 \%$, respectively as the abovementioned order in the first season. The corresponding values for the second season were $2.2,3.6$ and $0.6 \%$ in the same respect. The tested natural fertilizer

Fayoum J. Agric. Res. \& Dev., Vol. 28, No.1, January, 2014 
IMPACT OF SOME ALTERNATIVE FERTILIZERS SUCH AS.

treatments did obviously stimulate yield components of wheat, estimated increase percentages of number of spikes $/ \mathrm{m}^{2}$ of $3.4,1.5,0.8,5.6,4.9,3.9$ and $8.2 \%$ were supported for HA, RP, F, HA, RP, HA, F, RP, F and HA+ RP + F when compared with without natural fertilizer application in the first season. Similar trends were obtained in the second season for number of grains/spike and 1000-seed weight in the two seasons. It is obvious to notice that the mixed three natural fertilizers treatment scored the highest values of yield components of wheat. However, concerning with the individual natural fertilizer, humic acid recorded more yield components followed by rock phosphate and then feldspar. The interaction between nitrogen sources and natural fertilizer treatment was not significant, where means that wheat plants fertilized with ammonia gas and supplied with humic acid + rock phosphate + feldspar yielded the highest values of number of spikes $/ \mathrm{m}^{2}$, number of grains/spike and 1000-grain weight, while the plants received urea as nitrogen fertilizer and without natural fertilization showed the lowest ones.

\section{3- Grain and straw yields}

Results presented in Table (3) indicated that using ammonia gas as nitrogen source gave the highest significant grain and straw yield comparing with urea in both seasons. An increases of 3.4 and $4.2 \%$ in wheat grain and straw yields were attributed to using ammonia gas over urea in the first season. These values for the second season were 2.5 and $4.2 \%$ in the abovementioned order. Concerning the natural fertilizer treatments, the data reveal that both grain and straw yields of wheat were significantly affected by using natural fertilizers. It could arrange the effect of natural fertilizers on grain and straw yields as the following descending order : humic acid + rock phosphate + feldspar $>$ humic acid + rock phosphate $>$ humic acid + feldspar $>$ rock phosphate + feldspar $>$ humic acid $>$ rock phosphate $>$ feldspar $>$ without natural fertilization. It is obvious to observed that humic acid gave the highest wheat yields followed by rock phosphate and then feldspar, where the grain and straw yield attributed to these single natural fertilizers yielded 19.8 and $6.38,19.3$ and 6.17 , and 18.9 (ardab/fed) and 6.10 (ton/fed) in the first season, respectively. Similar trends were obtained in the second season. As the interaction between nitrogen sources and natural fertilizers, the statistical analysis show that both grain and straw yields were not significantly affected by the interaction between the two studied factors, which means that the highest grain and straw yields, were recorded for the plants injected by ammonia gas and treated with humic acid + rock phosphate + feldspar. On the other hand the wheat plants untreated with natural fertilizers and supplied with urea recorded the lowest grain and straw yields. 
$\underline{\text { Table } 2}$

Fayoum J. Agric. Res. \& Dev., Vol. 28, No.1, January, 2014 
IMPACT OF SOME ALTERNATIVE FERTILIZERS SUCH AS..........95

Table 3

Fayoum J. Agric. Res. \& Dev., Vol. 28, No.1, January, 2014 


\section{4- N,P and K uptake}

On basis of the grain and straw yields, N,P and $\mathrm{K}$ concentrations (Tables 5,6 and 7) and then total $\mathrm{N}, \mathrm{P}$ and $\mathrm{K}$ uptake by grain and straw were determined after harvesting (Table 3). The differences in nutrient uptake between the two nitrogen sources were significant. The highest N, P and $\mathrm{K}$ uptake (67.7, 21.1 and 119.5 in the first season, and 67.2, 20.9 and 117.9 $\mathrm{kg} / \mathrm{fed}$ in the second season, respectively were produced by wheat supplemented with ammonia gas. Incorporation into soil with ammonia gas promoted $\mathrm{N}, \mathrm{P}$ and $\mathrm{K}$ assimilation by wheat. An average percentage increases of 11.9, 3.4 and 2.6 were obtained for $\mathrm{N}, \mathrm{P}$ and $\mathrm{K}$ uptake due to ammonia gas over urea. The influence of increasing nutrient uptake caused by ammonia gas was more conspicuous in nitrogen uptake than the others. Regarding natural fertilizers, the results reveal that $\mathrm{N}, \mathrm{P}$ and $\mathrm{K}$ uptake by wheat were significantly responded to natural fertilizer treatments. As low as 49.7, 16.8 and 94.9 of $\mathrm{N}, \mathrm{P}$ and $\mathrm{K} \mathrm{kg} / \mathrm{fed}$ were accumulated in untreated wheat in the first season. The corresponding values in the second season were 51.4, 16.2 and 94.7. The highest N, P and K uptake (81.6, 26.1 and $146.9 \mathrm{~kg} / \mathrm{fed}$, respectively were produced by wheat supplemented with humic acid + rock phosphate + feldspar in the first season. It could be arranged the effect of single natural fertilizers on nutrient uptake as the following descending orders :HA > RP > feldspar for nitrogen uptake, RP > HA > feldspar for phosphorus uptake and feldspar > HA > RP for potassium uptake. It is obvious to notice that humic acid, rock phosphate and feldspar were more pronounced on nitrogen, phosphorus and potassium uptake, respectively. The interaction between treatments was not significant in both seasons. In general, the highest values of nutrient uptake were recorded for wheat plants supplemented with ammonia gas and received humic acid + rock phosphate + feldspar, while the plants untreated with natural fertilizers under urea fertilization recorded the lowers ones. 
IMPACT OF SOME ALTERNATIVE FERTILIZERS SUCH AS..........97

$\underline{\text { Table } 4}$

Fayoum J. Agric. Res. \& Dev., Vol. 28, No.1, January, 2014 
$\underline{\text { Table } 5}$

Fayoum J. Agric. Res. \& Dev., Vol. 28, No.1, January, 2014 


\section{5-Soil available N, P K}

The results in Table (4) show that nitrogen fertilizer sources had positive residual effect only on soil available nitrogen after harvest, while available phosphorus and potassium did not affect. Up to about 26.7 and $22.5 \%$ increases were attributed to using ammonia gas comparing with urea in the two studied seasons, respectively. With regard to natural fertilizers, the results indicate that neither rock phosphate nor feldspar did affect soil available nitrogen after harvest, which positively responded to humic acid treatment in both seasons. It could be notice that the differences effect between humic acid alone or in combined with the rock $\mathrm{P}$ and /or feldspar and the other treatments were not significant. The relative increases due to humic acid reached to 17.6 and $15.6 \%$ over control in the two seasons, respectively. Moreover, humic acid and /or rock phosphate were significantly improved soil available phosphorus at harvest in both seasons, where dual application of humic acid and rock phosphate gave the highest value. Humic acid plus rock $\mathrm{P}$ fertilized plants produced 143.6 and $110.3 \%$ available phosphorus higher than untreated plant in both seasons, respectively. Similarly, humic acid and /or feldspar had a positive residual effect on soil available potassium at harvest. Dual treated with humic acid plus feldspar gave soil available potassium higher than without natural fertilizers treatment by about 15.4 and $11.2 \%$ in both seasons, respectively.

The results show that soil available $\mathrm{N}, \mathrm{P}$ and $\mathrm{K}$ did not respond to the interaction between nitrogen sources and natural fertilizers. In general, the highest values of soil available nitrogen were obtained for plants received ammonia gas and humic acid;The plants supplemented with rock phosphate and humic acid recorded the highest value of available phosphorus, while the plants received feldspar or without natural fertilization showed the lowest available phosphorus. On the other hand feldspar and humic acid under ammonia gas produced the highest residual available potassium. 
IMPACT OF SOME ALTERNATIVE FERTILIZERS SUCH AS..........101

Table 7

Fayoum J. Agric. Res. \& Dev., Vol. 28, No.1, January, 2014 
The results show significant increases in plant height, dry weight/plant, number of spikes $/ \mathrm{m}^{2}$, number of grains/spike and grain and straw yields of wheat plants attributed to incorporation ammonia gas in soil comparing with urea. This may be explained by anhydrous ammonia $\left(\mathrm{NH}_{3}\right)$ when applied to moist soil will be reacts with soil water forming positive charged ammonia ions $\left(\mathrm{NH}_{4}^{+}\right)$and negative charged hydroxyl ions $\left(\mathrm{OH}^{-}\right)$. The clay particles and soil organic matter have negative charge in their surface, which attract and hold ammonia and not subjected to loss in soil. The plant roots absorbed ammonia, immediately bound to amino acids that may be translocated in roots and lower part of straw directly towards the growth centers (Sommer, 2005). On the other hand, Sanchez (1974) mentioned that when applied to a moist soil, urea is hydrolyzed into ammonia carbonate by enzyme urease, ammonia carbonate in the presence of water dissociates into ammonia and carbonate ions. Before hydrolysis, urea is as mobile as nitrate and may be leached down below the root zone by water. Similar results were obtained by Ismail et al (1996), and Siam et al (2008).

The effects of humic acid in increasing plant growth and yield could be due to induce micro biological stimulation (Petrovic et al, 1982). Malik and Azam (1985) reported that soaking wheat seeds in a solution of humic acid increased seedling growth, improved root development and enhanced uptake of water by roots. Humic acid influence plant growth both in direct and indirect ways. Indirectly, it improves physical, chemical and biological condition of soil. While directly, it increases chlorophyll content, accelerates plant respiration and hormonal growth responses, increases penetration in plant membranes, etc (Rajpar et al (2011). The increase in plant growth due to humic acid application was also reported previously (Taha et al, 2006; Ulukan, 2008; Khaled and Fawzy, 2011 and Tahir et al, 2011). The positive effect of rock phosphate and feldspar on wheat growth, yield components and grain and straw yields are mainly due to these natural fertilizers are good sources of both $\mathrm{P}$ and $\mathrm{K}$ for plant. The beneficial effects of rock phosphate and feldspar to crops were stated by many authors such as Nnadi and Haque (1988), and Akande et al (2005) for rock phosphate and Shaffeek et al (2005), and Abdel-Hak et al (2012). The promotive effect of humic acid on increasing the effect of natural $\mathrm{P}$ and $\mathrm{K}$ fertilizers on wheat productivity is mainly due to natural rocks can be greatly accelerated in the soil in the presence of organic acids such as humic acid (Kumari and Phogat, 2008 and Hellal et al, 2009).

As the result of a supplement of anhydrous ammonia, total N, P and K uptake were markedly increased when compared with a supplement of urea. This may be due to the promotive effect of anhydrous ammonia on grain and straw yields (Table 3), since total nutrient uptake calculated as multiplying grain yield by its nutrient concentration plus straw yield by its nutrient concentration. In this concern, Sommer (2005) mentioned that the roots uptake nitrogen out of there only if they are sufficiently supplied with

Fayoum J. Agric. Res. \& Dev., Vol. 28, No.1, January, 2014 
IMPACT OF SOME ALTERNATIVE FERTILIZERS SUCH AS

saccharides from the aboveground parts and plant can thus use nitrogen in metabolism of the nitrogenous compounds. The roots that participate in uptake of nitrogen and ammonia from depots (the injection of liquid ammonia fertilizer into soil in limited points of application creating so-called depots, become denser and branch due to saccarides produced in the aboveground part of plant and their distribution charges according the plant growth stage, they usually grow from the free soil towards depots. Also, Abd El-Kader (2002) attributed the enhancement of nutrients uptake to the decrease in soil $\mathrm{pH}$ caused by injection of anhydrous ammonia. These results are in line with those obtained by Abd El-Hamed et al (1996) and Ismail et al (1996).

The beneficial effects of humic acid are cleared through enhancing the chelating agent by active organic acids for nutrients and their easily uptake by plants (Salib, 2002). The positive effects of rock $\mathrm{P}$ and feldspar on nutrient uptake may be due to its effect on improve soil physical, chemical properties, as well as increased water uptake and nutrient availability, in turn increased nutrient uptake. Similar results were obtained by Rajput et al (2007) for rock $P$ and Hellal et al (2009) and El Sheref (2012) for feldspar. It is obvious to notice that there were notable increases in N,P and K uptake when combined humic acid with rock $\mathrm{P}$ and/or feldspar, which mainly due to the effect of humic acid on solubilizing insoluble phosphate and potassium and then increased its uptake (Stevenson, 1982). The synergistic action of organic material on the effect of rock $\mathrm{P}$ and feldspar on nutrient uptake was reported by many workers such as Gardner (1983), Akande et al (2005) and Badr (2006).

Apart from the fact that anhydrous ammonia resulted in greater amount of soil available nitrogen after harvest than urea. The residual phosphorus and potassium did not affect by nitrogen fertilizer sources. The effect of anhydrous ammonia on improved the residual available nitrogen could be due to ammonium cation released from anhydrous ammonia is holed by the negative charge of clay particles or organic matter and not lost, while nitrate anions resulted from urea hydrolysis leached down to the ground water (as mentioned before). The results also show that humic acid not only provide better amount of available N, P and $\mathrm{K}$ in soil after harvest but also enhanced the effect of both rock phosphate or feldspar on increasing soil available phosphorus or potassium, respectively. In this concern, Sinha (1972) reported that humic substance resulting from organic matter decomposition played a significant role in mobilizing insoluble phosphate.

Phosphate dissolution rates can be greatly accelerated in the soil in the presence of organic acids such as humic acids leading to 10-1000 fold higher soil solution $P$ concentrations (Fox and Comerford 1991). By the same manner, the solubilization rates of releasing potassium from feldspar was enhanced by organic acids (Badr, 2006 and Hellal et al, 2009).

\section{CONCLUSION:}

Fayoum J. Agric. Res. \& Dev., Vol. 28, No.1, January, 2014 
In conclusion, anhydrous ammonia at rate of $75 \mathrm{~kg} \mathrm{~N} / \mathrm{fed}$ and rock phosphate and feldspar as a potential supplement to phosphate and potassium fertilizers in combined with humic acids (300, 400 and $10 \mathrm{~kg} / \mathrm{fed}$, respectively) could be recommended for increase wheat productivity and improve soil fertility. Moreover, this technology is economical and environmental friendly.

\section{REFERENCES:}

Abdel - Hak, R.S.; El-Shazly, A.; El-Gazzar, A.; Shaaban, E.A. and El-Shamma, M.S. (2012). Response of Valencia orange trees to rock-feldspar application on reclaimed soil. J. of Appl. Sci. Res., 8(7): 3160-3165.

Abd El-Hamed, A.M.; Osman, A.Z.; Ismail, S.A. and Ahmed, F.M. (1996). Effect of nitrogen sources with different levels on garlic plants (Allium sativum L.). J. Agric. Sci. Mansoura Univ. 21(1): 423-429.

Abd El-Kader, M.G.(2002). Response of growth and yield of wheat (cv sids 7) to $\mathrm{Fe}$ and $\mathrm{Zn}$ application under ammonia injection. Ph. D Thesis, Fac of Agric. Moshtohor, Zagazig Univ. Egypt.

Akande, M.O.; Makinde, E.A. and Oluwatoyinbo, F.I. (2005). Effects of rock phosphate amended with poultry manure on soil available $\mathrm{P}$ and yield of maize and cowpea. African J. of Biotechnology, 4.5, 444-448.

Akinci, S.; Buyukkeskin, T.; Erogly, A. and Erdogan, B.E. (2009). The effect of humic acid on nutrient composition in broad bean (Vicia faba L.) roots. Not. Sci. Biol., 1(1): 81-87.

Andriesse, J.P. (1988). Nature and management of tropical peat soils. FAO Soils Bulletin No. 59, United Nations, Rome, 165.

Badr, M.A. (2006). Efficiency of K-feldspar combined with organic materials and silicate dissolving bacteria on tomato yield. J. Appl. Sci. Res., 2(12): 1191-1198.

Canellas, L.P.; Olivares,A.L.; Facanha, O.A.L., and Facanha, A.R. (2002). Humic acids isolated from earthworm compost enhance root elongation, lateral root emergence, and plasma membrane $\mathrm{H}^{+}$-ATPase activity in maize roots, Plant Physiology. 30: 1951-1957.

Chapman, H.D. and Pratt, P.F. (1961). Methods of Analysis for Soil, Plant and Water. Univ. of California, USA.

Chen, Y.; Nobili, M. and Aviad, T. (2004): Stimulatory effect of humic substances on plant growth. In: MAGDOFT., RAY R. (eds): Soil Organic Matter in Sustainable Agriculture. CRC Press, Washington.

El-Masry, A.A.; Gohar, N. and El-Akabawy, M.A. (2006). The effluence of nitrogenous fertilizer sources and some soil amendments on hull-less barley under alkali soil conditions. Egypt. J. of Appl. Sci., 21(11).

El-Sheref, G.F. (2012). Minimizing pollution with inorganic fertilizers through some nutritional techniques. Ph.D. Thesis, Fac of Agric., Moshtohor, Benha Univ., Egypt.

Fox, T.R. and Comerford, N.B. (1991). Low molecular weight organic acids in selected forest soils of the Southeastern USA. Soil Sci. Soc. Am. J., 54: 1139-1144.

Gardner, L.R. (1983). Mechanisms and kinetics of incongruent feldspar dissolution. Geol., 11: 418-421.

Hellal, F.A.; Abd El-Hady, M. and Ragab, A.A.M. (2009). Influence of organic amendments on nutrient availability and uptake by faba bean plants

Fayoum J. Agric. Res. \& Dev., Vol. 28, No.1, January, 2014 
fertilized by rock phosphate and feldspar. American-Eurasian J. Agric. \& Environ. Sci., 6(3): 271-279.

Ismail, S.A.; Osman, A.Z. and Abd El-Hamed, A.M. (1996). Effect of ammonia gas injection in alluvial soil with different rates, plant population and their interaction on garlic plants (Allium sativum L.). Egypt. J. Appl. Sci., 11(1): 151-160.

Jackson, M.L. (1973). "Soil Chemical Analysis". Prentice-Hall of India, Private and LTD., New Delhi, $\left(2^{\text {nd }}\right.$ ed), Indian.

Khaled, H. and Fawzy, H.A (2011). Effect of different levels of humic acids on the nutrient content, plant growth, and soil properties under conditions of salinity. Soil and Water Res., 6(1): 21-29.

Kumari, K. and Phogat, V.K. (2008). Rock phosphate: its availability and solubilization in the soil- a review. Agric. Rev., 29(2): 108-116.

Malik, K.A. and Azam, F. (1985). Effect of HA on wheat seedling growth. Exp. Environ. Bot. 25: 245-252.

Massoud, O.N.; Morsy, E. M. and El-Batanony, N.H. (2009). Field response of snap bean (Phaseolus vulgaris L.) to $\mathrm{N}_{2}$ - fixers Bacillus circulans and Arbuscular mycorrhizal fungi inoculation through accelerating rock phosphate and feldspar weathering. Australian J. Basic and Appl. Sci., 3(2): 844-852.

Morsy, M.A. (1994). Response of wheat to application methods and rates of some ammonical nitrogenous sources. Ph.D. Thesis, Fac. of Agric., Minia Univ. Egypt.

Nnadi, L.A. and Haque, I. (1988). Agronomic effectiveness of rock phosphate in an Andept of Ethiopia. Comm. Soil Sci. and Plant Anal. 19: 79-90.

Petrovic, P.; Vrrorovic, D. and Jablanovic, M. (1982). Investigation of biological effects of humic acids. Acta Biologiae et Medicinae Experimentals 7, 21-25.

Rajan, S.S.S.; Watkinson, J.H. and Sinclair, A.G. (1996). Phosphate rock for direct application to soils. Adv. Agron., 57:77-159.

Rajpar, M.B.B.; Zia-ul-hassan, A.N.S. and Tunio, S.D. (2011). Humic acid improves growth, yield and oil content of Brassica compestrisl. Pak. J. Agri., Agric. Eng., Vet. Sci., 27(2): 125-133.

Rajput, S.S.; Shaktawat, M.S. and Intodia, S.K. (2007). Residual effect of Udaipur rock phosphate sources and farmyard manure on productivity and nutrient uptake by succeeding maize (Zea mays) after wheat (Triticum aestivum). Indian J. of Agric. Sci., 77(3): 145-149.

Salib, M.S. (2002). The integrated effect of humic acid and imcronutrients in combination with effective micro - organisms on wheat and peanut grown on sandy soil. Zagazig J. Agric. Res. 29(6): 2033-2050.

Sanchez, F.A. (1974). Properties and Management of Soils in the Tropics. John Wiley and Sons, New York, USA., 194-195.

Schnitzer, M. (1992). Significance of soil organic matter in soil formation, transport processes in soils and in the formation of soil structure. Soil Utilization and soil Fertility. Volume 4, Humus Budget, 206: 63-81.

Shafeek, M.R.; El-Zeiny, O.A.H. and Ahmed, M.E. (2005). Effect of natural phosphate and potassium fertilizers on growth, yield and seed composition of pea plant in new reclaimed soils. Asian J. Plant Sci., 4(6): 608-612.

Fayoum J. Agric. Res. \& Dev., Vol. 28, No.1, January, 2014 
Ismail, S.A., et al,

Shahryari, R. and Mollasadeghi, V. (2011). Harvest index and its associated characters in winter wheat genotypes against terminal drought at presence of a peat derived humic fertilizer. Advances in Environmental Biology, 5(1): 162-165.

Siam, H.S.; Abd El-Kader, M.G. and Abd El-Fattah, M.S. (2008). Effect of ammonia gas and some micronutrients on maize plant (Zea mays). Iplant growth and mineral uptake. Australian J. of Basic and Applied Sci., 6(3): 462-473.

Sinha, M.K. (1972). Organo-metallic phosphates: IV. The solvent action of fulvic acids on insoluble phosphates. Plant and Soil, 37: 457-467.

Snedecor, G.W. and Cochran, W.G. (1980). "Statistical Methods" $7^{\text {th }}($ Ed)., Iowa State Univ. Press, Ames, Iowa, USA, pp: 255-269.

Sommer, K. (2005). CULTAN- Fertilization. Publishing House Th. Mann, Gelsen Kirchen, 218. (In Ger man).

Stevenson, F.J. (1982). Humus Chemistry. John Wiley and Sons, New York.

Taha, A.A.; Modaihsh, A.S. and Mahjoub, M.O. (2006). Effect of some humic acids on wheat plant grown in different soils. J. Agri. Sci. Mansoura Univ., 31(6): 4031- 4039.

Tahir, M.M.; Khurshid, M.; Khan, M.Z.; Abbasi, M.K. and Kazmi, M.H. (2011). Lignite-derived humic acid effect on growth of wheat plants in different soils. Soil Sci. Soc. of China, pedosphere, 21(1): 124-131.

Ulukan, H. (2008). Effect of soil applied humic acid at different sowing times on some yield components in wheat (Triticum spp.) hybrids. Intern. J. of Botany, 4(2): 164-175.

Fayoum J. Agric. Res. \& Dev., Vol. 28, No.1, January, 2014 
IMPACT OF SOME ALTERNATIVE FERTILIZERS SUCH AS.

تأثثير بعض بدائل الأسمدة مثل الامونيا الغازية وحامض الهيوميك وصخر الفوسفات والفلسبار على النمو والمحصول ومكوناته وامتصاص العناصر للقمح وكنلك صلاحية العناصر

صفوت احمد إسماعيل، احمد محمد عبد الحفيظ، اسامة احمد محمد جلال، حامد على عوض الله

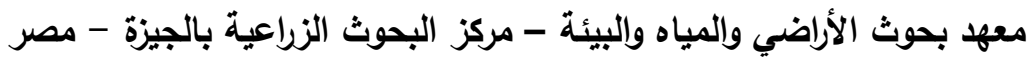

أجريت هذه الدراسة لتحديد تأثثير بعض بدائل الأسمدة مثل الحقن بالامونبا مقارنة باليوريا مع

اضافة بعض الأسمدة الطبيعية منل حامض الهيوميك وصخر الفوسفات والفلسبار منفرده او منبادلة على النمو والمحصول ومكوناته وامتصاص بعض العناصر لنبات القمح "صنف بني سويف ا" وكذللك على صلاحية بعض العناصر بعد الحصاد، حيث أجريت تجربه حقليه لمدة موسمين زراعيين

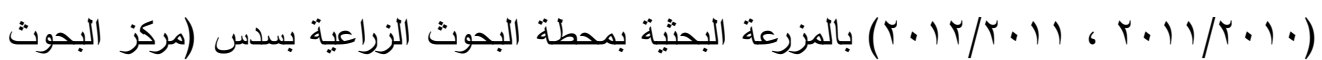
الزراعية) بمحافظة بنى سويف. وفيما يلى ملخص لاهم النتائج المتحصل عليها:

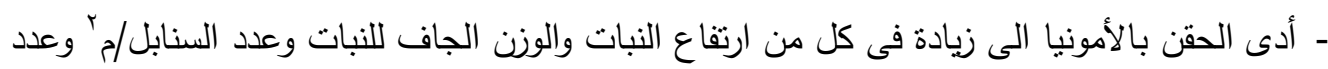

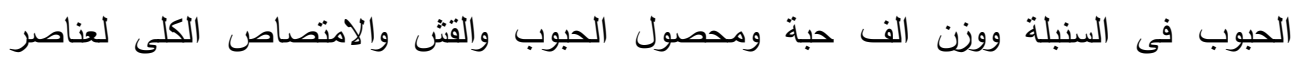
النيتزوجين والفوسفور والبوتاسيوم، كما أدى الحقن بالأمونيا الى زيادة صلاحية النيتروجين فى التربة

$$
\text { بعد الحصاد وذللك عند مقارنتها باليوريا. }
$$

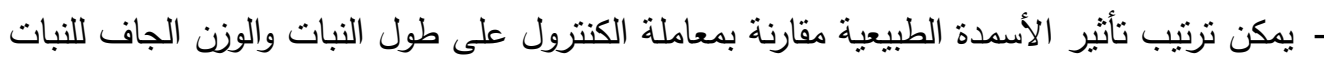
وعدد السنابل بالمتر المربع وعدد الحبوب بالسنبلة ومحصول الحبوب والقش ترتيبا تتازليا كما يلي:

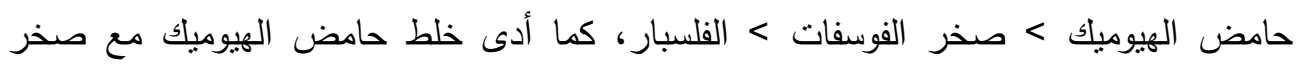
الفوسفات او الفلسبار او كلاهما إلى زيادة في ذلك التأثير مقارنة بإضافة كل سماد بمفرده. - أدى حامض الهيوميك وصخر الفوسفات والفلسبار إلى أعلى القيم لامتصاص النيتروجين والفوسفور

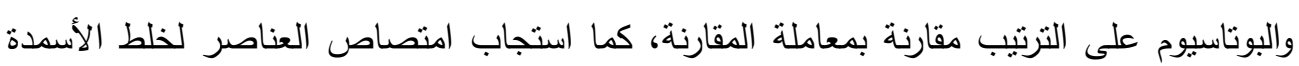

$$
\text { الطبيعية مع بعضها اكثر من استخدامها بمفردها. }
$$

- ازدادت صلاحية عنصر النيتروجين والفوسفور والبوتاسيوم بالتربة بعد الحصاد باضافة حامض بهان

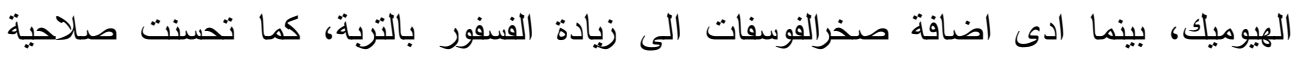

البوناسيوم بإضافة الفلسبار مقارنة بمعاملة المقارنة.

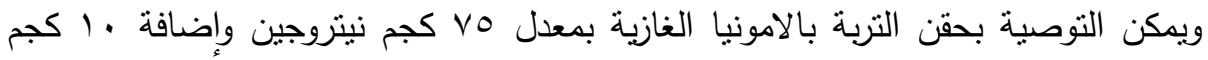

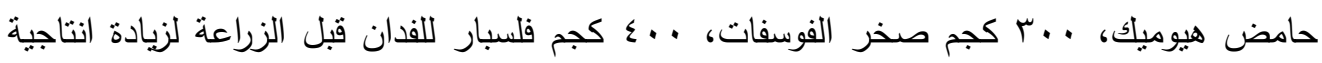
القمح وتحسين خصوبة التربة مع تقليل تكلفة استخدام الأسددة وعدم تلوث البيئة.

Fayoum J. Agric. Res. \& Dev., Vol. 28, No.1, January, 2014 